\title{
Pensions and the Extending Working Lives Agenda in the UK: The Impact on Women
}

\author{
Liam Foster ${ }^{1}$ (D) \\ Received: 20 September 2021 / Accepted: 17 November 2021 \\ (c) The Author(s) 2022
}

\begin{abstract}
Extending working lives (EWLs) has been a key policy response to the challenges presented by an ageing population in the United Kingdom (UK). This includes the use of pension policies to encourage working longer. However, opportunities and experiences of EWLs are not equal. While much has been written about EWLs more broadly, limited attention has been paid to connecting those EWLs policies associated with pensions and their potentially unequal impact on women. This article aims to address this gap, taking a feminist political-economy perspective to explore the structural constraints that shape EWLs and pensions. Initially it briefly introduces the EWLs agenda, before focussing on pension developments and their implications for EWLs, considering the gendered nature of these policies. Finally, it touches upon potential policy measures to mitigate the impact of these developments on women. It demonstrates how women's existing labour market and pension disadvantages have been largely overlooked in the development of EWLs policy, perpetuating or expanded many women's financial inequalities in later life. It highlights the need for a greater focus on gendered pension differences in developing EWLs policy to ensure women's circumstances are not adversely impacted on.
\end{abstract}

Keywords Discrimination · Extending working lives $\cdot$ Gender $\cdot$ Pensions · Retirement

\section{Introduction}

The move to extend working lives (EWLs thereafter), is a key European Union (EU) and United Kingdom (UK) policy response to the pressures of population ageing, including on pension systems (Finch, 2014). The life expectancy at birth

Liam Foster

L.Foster@sheffield.ac.uk

1 Senior Lecturer in Social Policy and Social Work, University of Sheffield, Department of Sociological Studies, University of Sheffield, Elmfield Building, Northumberland Road, Sheffield S10 2TU, England 
in England and Wales since the start of the 20th Century has increased from around 45 years to 79 years for men and 49 years to 83 years for women (ONS, 2020). These trends have led to debates regarding the sustainability of financing older age given rising old-age dependency ratios and a need to manage public spending on pensions (von Nordheim, 2016). The emergence of the EWLs agenda has flourished in the attempts to curtail rising state expenditure (Ebbinghaus \& Hofäcker, 2013; Lain, 2016). In effect, EWLs policies such as increasing the age at which people retire and the age of pension receipt both increase revenues by expanding the working population while also decreasing expenditure by reducing the number of beneficiaries (Kuitto \& Helmdag, 2021). In the UK, Ros Altmann (2015: 9) the former Pension's Minister, said:

as people are living longer, we need to rethink what retirement looks like.

This is not about forcing people to work on but supporting those who want to maintain a fuller working life ... our concept of retirement and ageing in a workforce must move with the times as people's lives and the population demographic changes.

This approach to 'rethinking retirement' has led to a variety of employment and pensions measures associated with EWLs to aide older people's participation in (productive) society (Foster \& Walker, 2021). The UK government has made clear the expected individual benefits of embracing these imperatives: 'working longer and taking control of when they retire can give individuals more money in later life and allow them to maintain their existing lifestyle' (Department for Work and Pensions (DWP) 2017a: 26). Within an environment of progressive welfare state retrenchment and a shift from decommodification to a greater emphasis on labour market participation, EWLs policy has been presented as enabling people's 'choices' and 'freedoms' while also promoting individual responsibility (Beach \& Bedell, 2019; Krekula \& Vickerstaff, 2020).

Despite the positive rhetoric surrounding EWLs, it is not always experienced in this manner. EWLs policies are not experienced equally, with choice distributed unevenly according to a myriad of interrelated factors (Lain, 2016; Porcellato et al., 2010). The reasons why individuals leave or remain in paid employment are numerous and complex (Swain, 2020). These include the financial status and the affordability of retirement, health, caring commitments, decisions of partners and/or close family members, job satisfaction, and job prospects (Brown \& Vickerstaff, 2011; Di Gessa et al., 2017; Finch, 2014). Pension and labour market policies, as well as the economic context, also provide important incentives and restrictions regarding work continuation (Kuitto \& Helmdag, 2021). It is these pension policies associated with EWLs which are the focus of this article. These include increasing the State Pension Age (SPA), closing early retirement schemes, increasing links between contributions and benefits, and providing opportunities to combine pensions and paid employment (Lain, 2016).

EWLs measures which increase the role of employment and earnings throughout the working life on pension income, have implications for choice in relation to retirement decisions, and tend to reinforce existing inequalities during working 
life in retirement (Kuitto \& Helmdag, 2021). These inequalities are especially apparent in relation the circumstances of many women who are more likely to have working lives which are typically shorter in length, more fragmented, and involve higher rates of part-time work than their male counterparts (Vickerstaff \& Loretto, 2017). This situation reflects normative expectations regarding gendered social roles, with women traditionally expected to prioritize unpaid caring roles, which are often applicable in later working life too (Ginn \& MacIntyre, 2013; Jandrić et al., 2019).

Although much has been written about EWLs, less attention has been given to linking those EWLs policies associated with pensions and their potentially unequal impact on women (Kuitto \& Helmdag, 2021). This article aims to address this, including connecting the previous work by Foster, 2018 on EWLs and pensions, Ní Léime et al. (2020) on EWLs and gender, with work on gender and pensions by (Foster \& Heneghan, 2018; Foster, 2010). In doing so it provides a springboard for further empirical work focusing on the role of EWLs pension policies on women. It takes a feminist political-economy perspective which considers the structural constraints that shape EWLs and pensions. It also incorporates a lifecourse perspective which provides a further antidote to the homogenisation of older workers (Krekula \& Vickerstaff, 2017), showing how the process of EWLs is shaped by individual's experiences, opportunities and choices within changing social norms and institutions (Wildman, 2020). Initially it will briefly chart the development of retirement in the UK and the EWLs agenda. It will then focus on the gendered nature of pension developments and their implications for EWLs, including increases in the SPA, changes to the State Pension, the promotion of private pensions and the development of auto-enrolment. Finally, it will briefly discuss potential policy measures to mitigate the impact of these developments on women, before concluding.

\section{Retirement and the EWLs}

Prior to the introduction of old age pensions voluntary retirement was a rare phenomenon, with older people often moved into 'light work' as they aged (Phillipson, 1982). Hannah (1986) stated that with the advent of the 'modern organisation', it became more common for employers and trade unions to seek a more routinised exit from the labour market via occupational pensions. Retirement as a distinct category, which was defined by age (of pension entitlement), subsequently gained further prominence with the extension of state pensions from 1948, in the form of a flat-rate pension, funded through National Insurance (NI) contributions (made by employees and employers) for men (aged 65) and women (aged 60) (Lain \& Loretto, 2016). For those who could afford them it was supplemented by occupational pensions, with national assistance being used by those without access to further provision. Pensions represented a form of institutionalisation of retirement and were employed to manage the labour market (Kohli, 2007; Phillipson, 2019). Retirement became structurally distinct from paid work, providing a clearly defined 'normative' phase of the life-course (Foster \& Walker, 2021; Phillipson et al., 2016). 
Between the late 1960s and mid-1990s, older men's employment rates fell markedly with policies employed to provide early retirement opportunities (Chandler \& Tetlow, 2014). However, following this attention then pivoted to focus on the potential of people to work longer (Laczko \& Phillipson, 1991), representing a significant change to previous debates around work and retirement. This emphasis on EWLs was accompanied by a narrative that demographic change was causing substantial pressure on the welfare state (Hofäcker et al., 2016; Phillipson, 2019). This led to several policy responses associated with EWLs, including raising SPAs, which were presented as an unavoidable response to the ageing population (DWP, 2014; OECD, 2006). In addition, there has been a growing emphasis in public discourse on the responsibility of older people to undertake longer paid employment to fund their retirement, implying a strong moralistic tone (Jandrić et al., 2019). The DWP (2014: 5) argued that 'early exit from the labour market can have serious implications for the health, well-being and incomes of individuals, and comes at a significant cost to the economy, business and society as a whole'. EWLs is imbued with a notion of obligation with the older worker having a duty to avoid becoming 'burdensome' for wider society (Wainwright et al., 2019). This discourse creates a new form of ageism, requiring 'continuation of work as the new legitimacy for a mature identity' (Taylor \& Earl, 2016: 254).

These moves have seen employment trends of older workers increase considerably over the last two decades. Men's average age of exit from the labour market was 65.2 years in 2020, compared with 63.3 years in 2000, whereas for women it was 64.3 years in 2020, an increase from 61.2 years in 2000 (TUC, 2021). However, for both men and women there is a significant fall in the employment rate above the age of 65 . Exit patterns from employment to retirement have also become progressively more heterogeneous and fragmented, 'evolving' in new and distinctive ways (Hallerod et al., 2013) with varied forms of work, including contractualization and casualisation, reshaping the end of working lives (Taylor et al., 2021). Women's increasing involvement in the labour market at all ages, tends to be disproportionately located in more precarious and flexible forms (Ginn \& MacIntyre, 2013), demonstrating the tensions with the EWLs narrative (Phillipson, 2019). This process represents a de-standardization of employment histories and retirement (Möhring, 2021), with the EWLs narrative playing an important role in re-positioning the place of retirement within the lifecourse (Phillipson, 2019).

EWLs policies have tended to be a mixture of permissive measures such as age discrimination legislation and the ending of mandatory retirement ages (in 2011 the Default Retirement Age (DRA) of 65 was abolished), effectively outlawing mandatory retirement, and involuntary, such as the increases in the SPA (Airey \& Jandrić, 2020). The former is often lauded as having a positive impact on extending individual rights, and 'freeing people from the tyranny of being forced to stop working simply because they reach a certain age' (Krekula \& Vickerstaff, 2020: 37). In practice it encourages people with inadequate retirement savings to continue to work and contribute to pensions (Botti et al., 2011). Ultimately, as Street \& Ní Léime (2020) point out, EWLs relies on the assumption that paid employment is readily available to older workers, yet there is evidence that this is not always the case. It also assumes older people's capacity to take on paid work, failing to adequately comprehend the impact of structural inequities (Depp \& Jeste, 2006; Jandrić et al., 2019). 
Powell \& Taylor (2016) identified three main strands to the government's EWLs policy agenda: welfare-based attempts to reduce the number of working aged people accessing state benefits moving them into paid employment using tougher eligibility tests for benefits and intensive, targeted support for job-seekers; attempting to remove barriers to EWLs by removing compulsory retirement and addressing age discrimination; and pensions measures including increasing the ages at which the state pension can be claimed. It is this final strand, and its gendered nature, that is the primary focus of this article.

\section{Gender, Pensions and extending working lives}

Pension system reforms are fundamental to EWLs, providing both incentives and an environment for the supply and demand of the labour of older workers (Botti et al., 2011). They can also provide a source of wealth, which may enable choice regarding the timing of retirement (Chandler \& Tetlow, 2014). In recent years the focus on sustainability in response to fiscal pressures has been a key driver for major reforms to UK pensions (Kuitto \& Helmdag, 2021). These have included raising the SPA, restricting early retirement routes and benefits, providing incentives for delaying state pension receipt, and increasing the contribution period entitling a full state pension. Pension reforms have emphasised the link between pension contributions throughout the lifecourse and the pensions received in retirement (Price, 2015), and on the responsibility of individuals to plan for their own retirement (Foster, 2017; Vickerstaff \& Cox, 2005). This has strengthened the link between the length of working life, including in later working life, life-time earnings and the adequacy of pensions (Kuitto \& Helmdag, 2021).

These increasingly individualised risks and pressures are not experienced equally (Berry, 2021; Krekula \& Vickerstaff, 2020), with women less likely to have opportunities to build up significant pension incomes in their own right (Ginn, 2003; Lain et al., 2019). Therefore, it is important to explore the implications of these pension developments associated with EWLs on women, especially given that there remain significant gaps in the literature in relation to the experience of retirement transitions of older women (Taylor et al., 2021). Locating policies regarding EWLs primarily in neoliberal notions of individual responsibility has the danger of overlooking the gendered nature of work and retirement, homogenising the process of retirement (Foster, 2018). A one-size-fits-all EWLs policy approach is based on assumptions of the un-gendered adult worker model which assumes work is available to older workers; that they are in a position to be employed including being sufficiently healthy to engage in employment, in addition to earning enough to contribute to a pension (Ní Léime \& Loretto, 2017). Taking a feminist political economy of ageing position, it is evident that these assumptions are not applicable for many women, who are more likely than their male counterparts to face challenges associated with gendered norms of care (for both children and other forms of care), disjointed work histories, ageist attitudes among employers, and low pay (Airey \& Jandrić, 2020; Ginn, 2003; Price, 2007). Women are also more likely to exit the workforce as a result of chronic health conditions (Beach \& Bedell, 2019). Therefore, pension developments 
associated with EWLs need to be understood within this broader gendered context, recognising that EWLs may not be an option for some people.

The impact of economic conditions, policy developments and gendered social norms throughout the lifecourse impact on later life outcomes (Ní Léime \& Street, 2017), with individuals who have more fragmented pension contribution histories having a smaller opportunity to build up pension pots. On average British women receive $25 \%$ less in state pension than men and women's private pension savings are only half their male counterparts (PPI, 2016). These disparities are also associated with women's, on average, earlier departure from the workforce than their male counterparts (TUC, 2021). This has prompted governments to characterise older women as representing a form of 'untapped potential' (Jandrić et al., 2019). Working longer may also be even more important for women given their more diverse employment histories, to ensure adequate pensions (Kuitto \& Helmdag, 2021). Finch (2014) has demonstrated that the 'opportunity costs' experienced during the working life, along with an emphasis on individual responsibility, may force some women to pursue EWLs for economic reasons.

Ní Léime and Loretto (2017) observe that these differences in engagement with paid employment and pensions have profound implications for the EWLs agenda, with women often ill-served by current foci and policies. It is to these state pension policies associated with EWLs, and the gendered implications, which the article now turns, before it considers private pensions.

\section{Gender and state pensions}

Prior to 2016, the UK pension system was based on a complex three-tier system: (1) the Basic State Pension (BSP); (2) the earnings-related Additional State Pension; and (3) private pensions. The two State Pension elements were replaced with a flat-rate, Single-tier State Pension (STP) in 2016 (for new pensioners) which is dependent on an individual's contribution record (Crawford et al., 2013). In line with increasing links between employment and pensions, to qualify for the full STP individuals are required to have paid 35 full years of NI contributions, rather than the 30 years under the old system, meaning people may need to work longer to qualify for the full STP (Airey \& Jandrić, 2020). While it is possible to claim NI credits for time out of the labour market under certain circumstances, including certain caring responsibilities and disabilities, it is still highly dependent on employment throughout the lifecourse which may disproportionately penalise women (Foster \& Heneghan, 2018).

The introduction of the STP is likely to impact on decisions regarding EWLs. It has been estimated that those women who are low-paid and have a full contribution record will be better-off under the new STP system (Airey \& Jandrić, 2020). However, there will be winners and losers depending on individual circumstances (Crawford et al., 2013). The reforms to the state pension may ultimately provide a foundation for private pensions through additional clarity about the (relatively low) level of state provision people are likely to receive (Berry, 2021; Price, 2007). In response people may need to work longer and increase private saving to compensate 
for this. Women will be adversely affected by the increased years of NI contributions (or credits) required to qualify for full entitlement of the STP. Furthermore, some women are unaware that if their partner's earnings deem them ineligible for child benefit for a child under 12, they are still required to apply for it in order to receive these NI credits (Dixon, 2020). By continuing to link state pension entitlement to NI, governments show a preference for a heteropatriarchal experience of work, which privileges 'an idealized worker who is able to perform an expected, masculinized occupational life-course' (Grady, 2015: 450). The reality is that the feasibility of women being able to reach the full 35 years of NI credits is far from certain (Vickerstaff \& Loretto, 2017; Wildman, 2020).

Payments from the STP start once the SPA is reached (unless receipt is deferred). It is as recently as early 2010, that women received a state pension at the age of 60, and men at 65 (Mayhew, 2021). The impact of the Pensions Act 2011, accelerated the pace of change, resulting in the equalisation of men and women's SPA occurring by November 2018 (at 65) and moving to 66 in 2020, affecting around 2.6 million women in Great Britain (Thurley \& Keen, 2018). As a result of the increasing speed of pension age equalisation, of these, about 500,000 women must wait between a year and 18 months extra to access their state pension (Ginn \& MacIntyre, 2013; Holman et al., 2020). The SPA will become 67 in 2028 and the Cridland review (2017) recommended increasing the SPA to 68 between 2037 and 2039, which the government indicated it intends to follow (Airey \& Jandrić, 2020). These recommendations are part of a 'series of measures designed to extend the duration of working life' (Wainwright et al., 2019: 2398). These trends are occurring even though public attitudes are largely against projected state pension age rises, with $77 \%$ of UK citizens considering them to be 'unfair' (Macnicol, 2015). Earlier deaths among the most vulnerable groups are associated with growing social inequalities, resulting in differences in lengths of access to the state pension (Street \& Ní Léime, 2020). Therefore, a blanket mandate for working to older ages for vulnerable groups may be deemed inequitable (Street \& Ní Léime, 2020).

The acceleration of the SPA has been greeted with a strong backlash, both from within parliament and the general public, and linked to negative mental and physical health effects for the women affected (Carrino et al., 2018). It led to the establishment of the Women Against State Pension Inequality (WASPI) campaign, who have played an active role in campaigning against the perceived injustices caused to women by the lack of notice that the government provided regarding changes to the SPA and the rapidity of the changes (Della Guista \& Longhi, 2020). The women affected received on average around 16 months' notice before turning 60 (Work \& Pensions Committee, 2015), despite Cridland (2017) recommending that a minimum of ten years' notice is necessary to allow for enough planning. The changes in SPA may also be problematic for those who have already made employment, saving and retirement decisions based on a particular SPA who are not in a position to adjust to an increased SPA by working or saving longer (Macnicol, 2015).

The UK may be deemed to be working towards a 'self-reliance' model (Lain, 2016) where, although most individuals can theoretically work past age 65 (with the removal of the DRA), rapid SPA rises offer little realistic alternative to employment for many. While in high-income groups the state pension represents a comparatively 
marginal factor in their financial planning given that they are more likely to have built up private pensions and other financial assets (Jandrić et al., 2019), middle to lower income groups (among whom women are overrepresented) are more likely to be 'nudged' to delay retirement because of SPA increases (Weyman et al., 2012). The SPA can therefore have an anchoring effect on retirement, with these changes increasing the extent to which some individuals remain reliant on employment until older ages. This is indicated by the fact that the biggest increases in rates of employment have been among women aged 60 to 65 and men aged 65, reflecting the effect of the increases in SPA on these age groups (TUC, 2021). Although long-term trends have witnessed older women's employment rates increasing for many years, it is noticeable that these have recently been more substantial (Airey \& Jandrić, 2020). Cribb et al. (2014) suggested that increases in the female SPA explained an estimated $85 \%$ of the growth in the employment rate of older women that occurred since 2010. However, Beach \& Bedell (2019) question the level of impact of reforms pointing towards a range of other factors linked to EWLs including a strengthening work orientation, and improvements to health and education.

It is important to note that state pension provision represents a larger part of women's retirement income than for men in all income groups (Kuitto et al., 2021; Pensions Policy Institute (PPI), 2016). Therefore, many women have been required to continue to work longer as they could not afford to retire (Foster, 2018) resulting in some workers becoming locked into lower paid, more precarious forms of employment to avoid poverty (OECD, 2018). In addition, there are those who through lack of opportunities, poor health and caring responsibilities are not able to respond to these developments, even if they are aware of them, leaving the labour market prior to eligibility for the state pension (Di Gessa et al., 2017; Price et al., 2015). For instance, women aged 60 to 65 are almost three times more likely than men to be out of work as a result of looking after a family member or home (TUC, 2021). Older women whose plans in terms of employment are 'blown off course' as a result of caring commitments are at a high risk of having an inadequate income in later life or needing to work longer (Vickerstaff, 2006). These trends have led Street \& Ní Léime (2020: 104) to note 'as state retirement ages increase, women appear likely to be disproportionately affected by persistent gaps in pay and breaks from employment needed to perform the unpaid work their societies expect them to do'. This risks many women being left with a low income, particularly as the broader welfare state is relatively poor in providing alternative forms of income for people who exit work early, with benefits for unemployment and ill health worth only half the state pension (Airey \& Jandrić, 2020; Lain et al., 2019). Ginn \& MacIntyre (2013) referred to some older women as increasingly finding themselves 'in limbo', finding themselves too young to be entitled to a state pension but too ill or occupied with caring to work the extent they need to. Therefore, raising the SPA is not a benign policy measure, especially for those on lower incomes, where the state pension represents the lynchpin of income in retirement (Wainwright et al., 2019).

Changes to the SPA have also been accompanied by increases in the age at which the PC can be received, an important source of income for many women (Ginn \& MacIntyre, 2013). The Pension Credit (PC), designed as a means-tested top-up for people in older age with a low income, previously provided additional source of 
retirement income for men and women from age 60. It was perceived to provide a disincentive to find work for older unemployed people (Jandrić et al., 2019). These developments create greater pressure for individuals to continue to work in older age, especially as unemployment and ill health-related benefits are worth less than the state pension and PC (Lain, 2016). This is despite the state pension in the UK having the lowest replacement rates of pre-retirement income in the OECD. In 2017, the UK net replacement rate for individuals entitled to the full state pension was $29 \%$ for full-career average earners, which compared unfavourably to the OECD average of $63 \%$ (Airey \& Jandrić, 2020). Since 1990 the difference between job seekers allowance and PC has more than quadrupled, from 30 to $129 \%$, leading to rising poverty rates among those just below SPA (TUC, 2021).

Further strategies used in order to encourage people to delay their retirement include the possibility of deferring state pension receipt while also increasing the final pension (Lain, 2016). Individuals who have reached the SPA can also continue in employment while claiming the state pension. These individuals are exempt from paying NI contributions. However, lack of awareness of the incentives available is notable. For instance, only around half of older people are aware they will not be required to pay NI contributions after pension age (Altmann, 2015). This reflects a wider lack of knowledge regarding pensions, especially among women (Foster, 2017; James et al., 2020).

\section{Gender and private pensions}

Private pension provision has become a key building block of ageing policy (Powell \& Taylor, 2016), with neo-liberal pension policies emphasising a position of laissez-faire, with minimal state intervention. At the same time, increased financialization of pensions has led to increasing levels of risk and responsibility on individuals (Berry, 2021), which impacts on their capacity to save and decisions about when to retire. Ageing populations, changing accounting standards (including EU regulation in 2005) and challenging equity markets, increased the pressure on British firms to limit pension liabilities and individualise risks (Ebbinghaus, 2021). In the UK this led to a shift towards Defined Contribution (DC) schemes from Defined Benefit (DB) schemes. For instance, the number of workers in private sector DB schemes still open to new members is only 1 million despite the total private sector workforce being 23 million (McClymont \& Tarrant, 2016). There is no guaranteed income in retirement with DC schemes, unlike DB ones, as retirement income is dependent on how the funds invested perform. It represents a shift from a more buffered and collective approach to individualised exposure to financial market risks, with individuals increasingly in charge of managing their own savings in addition to their retirement transitions (Krekula \& Vickerstaff, 2020). Given that DB schemes provide a guaranteed income, employees in these types of schemes are more likely to retire prior to the SPA than DC scheme members (Phillipson \& Smith, 2006). In addition, DB pensions have been organised around the schemes 'normal retirement ages', with less incentive to defer receipt. In effect this may encourage people to receive their occupational pension and leave employment. The unpredictability of DC schemes 
is likely to encourage further employment beyond age 65 in the future, especially if pension 'pots' decline during periods of financial turmoil (Lain \& Loretto, 2016).

Private pensions represent a significant source of gendered income inequality in later life. ONS (2018) figures show that between July 2014 and June 2016, for men aged $65+$ median private pension wealth was $£ 160,700$ which was more than twice as much as for women of the equivalent age $(£ 67,500)$. These trends are largely caused by differing gendered lifetime work and family histories, and the fact that typical male working patterns are still the primary reference point for calculating pension entitlements (Grady, 2015). Pension systems which maintain a close connection between lifetime earnings and pensions through a considerable emphasis on private pension provision and a residual state scheme serve to exacerbate the accumulated effects of gendered work histories on retirement income (Foster \& Heneghan, 2018; Ginn, 2003). Time out of employment in order to undertake childcare, results in many women missing out on early career advancement, pay rises and private pension contributions, which are compounded over a lifetime of work (Street \& Ní Léime, 2020). The process of individualising risk and the responsibility in pension provision results in many women being required to work longer to be able to afford to retire. The shift from DB pensions to DC schemes and the associated increases in individual risk have presented challenges for women who can illafford poor investment performance given their smaller pension pots, although they may nudge people to retire early when investment performance is vibrant. There is a greater likelihood of women being required to stay in work for longer in order to attempt to recover any investment losses resulting from, for instance, the aftermath of the global financial crisis (Berry, 2021).

Further reforms to private pensions were aimed at promoting EWLs. For instance, changes to tax rules in 2006 which inhibited taking paid work in addition to drawing a pension from the same employer were implemented (Vickerstaff, 2006). This had caused some people to stop working altogether, rather than search for another job (Chandler \& Tetlow, 2014). An early retirement deterrent was also put in place in 2010 with the age threshold for drawing a private pension expanded from 50 to 55 years (Powell \& Taylor, 2016; Principi et al., 2018). There have also been concerns about levels of saving for retirement, with the government estimating that about 12 million people below the SPA were likely to have inadequate income in retirement (DWP, 2014). These concerns, and questions about individuals' ability to plan for their own retirement, has been used to support the 'libertarian paternalism' inherent in auto-enrolment (Clark \& Strauss, 2008), which uses a form of 'soft' compulsion into non-state pensions (Thaler \& Sunstein, 2008). Auto-enrolment has played an important role in individualizing pension responsibility and encouraging pension saving, with implications for decisions about whether to work longer. Since October 2012, auto-enrolment has been gradually introduced depending on the size of the employer, to automatically enroll eligible individuals (generally low-to-median earners) who do not have access to good quality workplace pensions into a low-cost portable occupational pension, while allowing existing schemes, which provide benefits or contributions above the National Employment Savings Trust (NEST) (the default option auto-enrolment scheme) minimum, to continue. The state fulfils the role of 
enabler while, paradoxically, commanding individual choice and responsibility (Foster, 2010; Mabbett, 2012; Strauss, 2014).

It assumes that, overall, people understand the need to save for retirement yet do not proactively enroll in a pension (MacLeod et al., 2012). The logic behind autoenrolment is that behavioural barriers, including cynicism, myopia and inertia, may still stymie increases in saving despite information and structured advice having the potential to improve understanding (Foster, 2017). It was predicted that financial incentives of investment growth, along with employer and government contributions would persuade most of the auto-enrolled tempted to opt-out to resist (Wicks \& Horack, 2009). In 2017, less than one in ten had exercised their right to opt out (DWP, 2017b). Auto-enrolment has largely been presented as a success given the increasing number of people saving for retirement (Prabhakar, 2017). Pension participation had risen by over 31 percentage points since 2012 to $73 \%$ of eligible employees in the private sector in 2016, reducing levels of under-saving by 2 million people (DWP, 2017b).

It has been stated that auto-enrolment will 'help more women to save for later life' (Webb, 2014). There is evidence to suggest that it has increased the number of women saving for pensions. In 2012, the start of phased auto-enrolment, $40 \%$ of eligible women employed in the private sector saved into a workplace pension, which rose to $73 \%$ in 2016 (DWP, 2017b). Despite this pension inequalities will continue to persist, and pension pots will have grown to $£ 50,514$ for men and $£ 40,332$ for women in 40 years’ time (assuming a 3\% investment growth) (Now: Pensions, 2018). Auto-enrolment still excludes more women than men, given that it does not provide credits for times out of employment and it also excludes the lowest earners, among whom women are overrepresented (Beach \& Bedell, 2019; PPI, 2018; Price, 2007). For instance, 1.2 million women (in relationships) with dependent children miss out on auto-enrolment contributions because they are currently looking after their family, while a further 1.4 million employed mothers with dependent children do not earn above the $£ 10,000$ threshold to qualify for auto-enrolment contributions (Jethwa, 2019). The PPI (2018) found that of employees earning less than the auto-enrolment trigger over three quarters $(77 \%)$ were women. Over $50 \%$ of part-time workers earn less than the auto-enrolment trigger and $81 \%$ of part-time workers are women (DWP, 2017b). Furthermore, almost 106,000 working people are not being auto-enrolled into a pension because their earnings come from more than one job with $70 \%$ of these being women (Citizens Advice, 2017). NOW: Pensions' Director of Policy, Adrian Boulding, has referred to these disparities as a form of 'covert sexual discrimination' (Now: Pensions, 2016).

Auto-enrolment has led to an expansion in the proportion of DC pension schemes, including the default auto-enrolment option, the NEST, and a corresponding decline in DB schemes (Airey \& Jandrić, 2020). It is unclear whether it will pay for people to save into auto-enrolment schemes as DC schemes operate in a way in which there is no guarantee the fund at retirement will exceed contributions. The current minimum contribution rates are also potentially too low to build a pension pot which provides a decent standard of living in retirement (Clark et al., 2012; TUC, 2021). Thaler \& Benartzi (2004) state that the inertia that rationalises auto-enrolment can lead to low saving rates among participants, given that once workers are enrolled into a scheme they tend to stick to the same savings rate, rather than increasing their contributions 
or undertaking additional saving. Default options are also regularly interpreted as an endorsement by the government, or their employer, as to where they should contribute and even the extent (Lusardi \& Mitchell, 2014). This presents a risk that people will end up with lower levels of pension saving than expected. This is particularly problematic for women with low earnings (Foster \& Heneghan, 2018). Phillipson et al. (2016) state that regardless of these reforms, limited pensions will remain a key feature for many groups, in effect reflecting precarities in the labour market in addition to poor market performance of DC type schemes. In combination with increases in the SPA, this may ultimately lead to women working longer in order to be able to afford to retire with an adequate income.

Over recent years occupational pensions have been shaped around more flexible retirement pathways, including possibilities to EWLs (Airey \& Jandrić, 2020; OECD, 2018). In 2015, individuals aged 55 + with savings in DC pension schemes were provided with a range of measures to offer pension flexibility. Individuals with DC pensions no longer face a retirement 'cliff edge' and can essentially mix non-employment and employment sources of income, with the potential to phase retirement (Airey \& Jandrić, 2020). Although annuities can still be purchased, the whole pensions pot can be taken in cash, funds can be left invested while withdrawing income through drawdown, or the pot can be untouched. As Foster \& Heneghan (2018) has shown these 'pension freedoms' have significant implications for the decumulation phase of autoenrolment pensions and may be perceived as diametrically opposed to the libertarian paternalism inherent in auto-enrolment. Given that auto-enrolment will lead to the expansion of DC pots, pension freedoms will take on a greater significance.

This process has intensified the individualisation of financial market hazards and longevity risks, in order to promote choice and freedom in accordance with financialisation (Ebbinghaus, 2021). How informed people are about appropriate investment decisions is a matter for concern. The Financial Conduct Authority (FCA) (2017: 15) is 'particularly concerned that consumers end up with an investment strategy that may not be suitable given the consumers' risk tolerance and what they intend to do with their pots in the future'. Furthermore, if people in their $50 \mathrm{~s}$ and early $60 \mathrm{~s}$ deem it necessary to draw on their retirement savings to manage until a rising SPA, this will inevitably reduce access to resources later in retirement. For women, the risk of a wrong decision is especially high given that more unpredictable careers and smaller pension funds, combined with the uncertainties of investment returns, charges and annuities (WBG, 2020). Decision-making is especially challenging where women have unpredictable life-course trajectories (Price, 2015) and possess limited pension knowledge (James, 2020). On average women have lower levels of self-reported pension knowledge than their male counterparts (Scottish Widows, 2019) with $41 \%$ of men stating they know 'a lot' or 'a fair amount' about workplace pensions compared to just $33 \%$ of women (DWP, 2020). Low levels of pension savings, which are more common among women, or poor savings strategies may result in people having to work longer than expected or re-entering the paid labour market in older age. 


\section{Discussion}

This article has shown that EWLs policies are deemed as an inevitable response to population ageing (Higgs \& Gilleard, 2010). Pension policies have represented an important strand of EWLs policy, with increasing SPA and the eradication of early retirement options in state pensions, key examples of responses focused on EWLs and reducing the 'burden' on the state. Other pension policies such as a move to DC schemes (characterised by greater uncertainty regarding returns), while less explicitly focused on EWLs, may work in tandem with changes to the state pension, to encourage people to work longer. The changes to pension schemes are consistent with the prevailing neo-liberal economic and political context, often framed as both an economic necessity as well as a moral imperative, while also offering greater choice and control over employment in later life (Airey \& Jandrić, 2020). Although it is presented in 'rhetoric as extending working lives in order to value the talent and skills of older workers, policymakers' motivations are more consistent with delaying retirement, cheapening state pensions and valorising pension markets' (Ní Léime \& Street, 2017: 479).

These developments and the move from mass fixed-age retirement, to a more diverse range of individual pathways emphasising EWLs has been particularly problematic for women (Vickerstaff \& Loretto, 2017). This rhetoric of choice and freedom fails to adequately engage with the potential barriers to later life employment, including poor health, caring responsibilities and (gendered) ageism (Jandrić et al., 2019). This may mean women are unable to work longer and accumulate additional retirement income or need to take poorly paid insecure employment. There is also a danger that the EWLs agenda will result in increases in poverty levels prior to retirement due to unemployment and ill health-related benefits being worth less than the State Pension and PC (Lain, 2016; TUC, 2021).

EWLs policies fail to tackle gender inequalities at home and work. Women's employment is influenced by various factors which 'underline the dangers of raising pension ages in the absence of a broader set of policies designed to support women (and men) at different phases of the lifecourse' (Phillipson, 2019: 630). In practice the current UK pension system institutionalises disadvantages which occur in the labour market through not providing adequate recognition to non-heteropatriarchal contributions that diverge from typical male work patterns (Grady, 2015). This focus on encouraging individual responsibility for working longer and saving more is commonly developed with an idealised 'adult worker' in mind, characterised by employment traits associated with men's typical experiences (Jandrić et al., 2019; Ní Léime \& Loretto, 2017; Wahrendorf et al., 2017). The gendered nature of employment and retirement transitions 'defines simple binary categories of a worker's status as either working or in retirement' (Taylor et al., 2021: 53). This approach oversimplifies and devalues the concurrent, multiple responsibilities and activities in spheres of work, care, leisure and volunteering that women often take on.

The pension developments risk rendering gender inequalities ever more invisible (Jandrić et al., 2019). It is apparent that these lifecourse trajectories have 
become all the more important for retirement with recent EWLs reforms strengthening links between lifetime employment, introducing measures to lengthen working lives and emphasising the role of private pensions (Kuitto et al., 2021). This includes the introduction of auto-enrolment which while bringing some women into pension saving, also operates in a manner which excludes many low paid women and does not incorporate credits for times of caring (Prabhakar, 2017). These policies fail to acknowledge the diversity of people's lifecourses, underscoring the significance of rejecting a 'one-size-fits-all' model of extended working (Wildman, 2020).

Women's greater poverty risk in later life, is in large part associated with their systematic disadvantage within masculinised private pension systems which are heavily earnings-related (Airey \& Jandrić, 2020). Furthermore, as women are more likely than men to be dependent on state pensions, the changes to SPA have important implications for both their income and timing of retirement. This has presented challenges for those women unaware of the changes to SPA (Holman et al., 2020). EWLs has resulted in new inequalities. For instance, raising the SPA generates inequalities linked to contrasting experiences in terms of health, finances and social relationships (Phillipson, 2019). Furthermore, the increase in the number of years of NI required to accumulate a full state pension in the STP, are problematic for women with a more fragmented work history and may compel them to work longer (Phillipson, 2019). Women 'choosing' to EWLs to avoid later-life poverty should not be seen as a policy success (Wildman, 2020).

A feminist political economy of ageing perspective highlights the need to consider gendered societal norms of caring, conditions in the economy and related employment policies at all phases of the lifecourse for a full impact of work in later life and pension reforms (Ní Léime \& Loretto, 2017). It promotes the need for an EWLs strategy that recognises the various trajectories women often experience without penalising women (and men) who diverge from traditional male patterns of employment. There is a 'need for comprehensive and appropriately refined policies that take lifecourse issues seriously, since the interconnectedness of lifecourse trajectories and later life outcomes is undeniable' (Street and Ní Léime, 2020: 109).

Table 1 summarises some of the key pension measures associated with EWLs, and their gendered implications, before outlining some potential policy mechanisms for reducing the gendered nature of the pension developments. For instance, it proposes that the manner in which NI credits in the state pension are built up needs to be adjusted, as women miss out on entitlements because they are unaware of the processes required (Dixon, 2020). WASPI have argued that women adversely affected by increasing the speed of equalisation (and increases in pension ages) who were provided with insufficient notice should be compensated (Thurley \& McInnes, 2019). However, Pemberton (2017) asserts that many of the issues created by the rise in the SPA are also experienced by men in the same cohort, who also face challenges adjusting to an increase in pension age. Instead, he expressed concerns around the 'complexities of the UK's byzantine and profoundly ungenerous system of welfare benefits' (514). The TUC (2021) has even suggested the prospect of abandoning planned increases to the SPA beyond the current level of 66. 


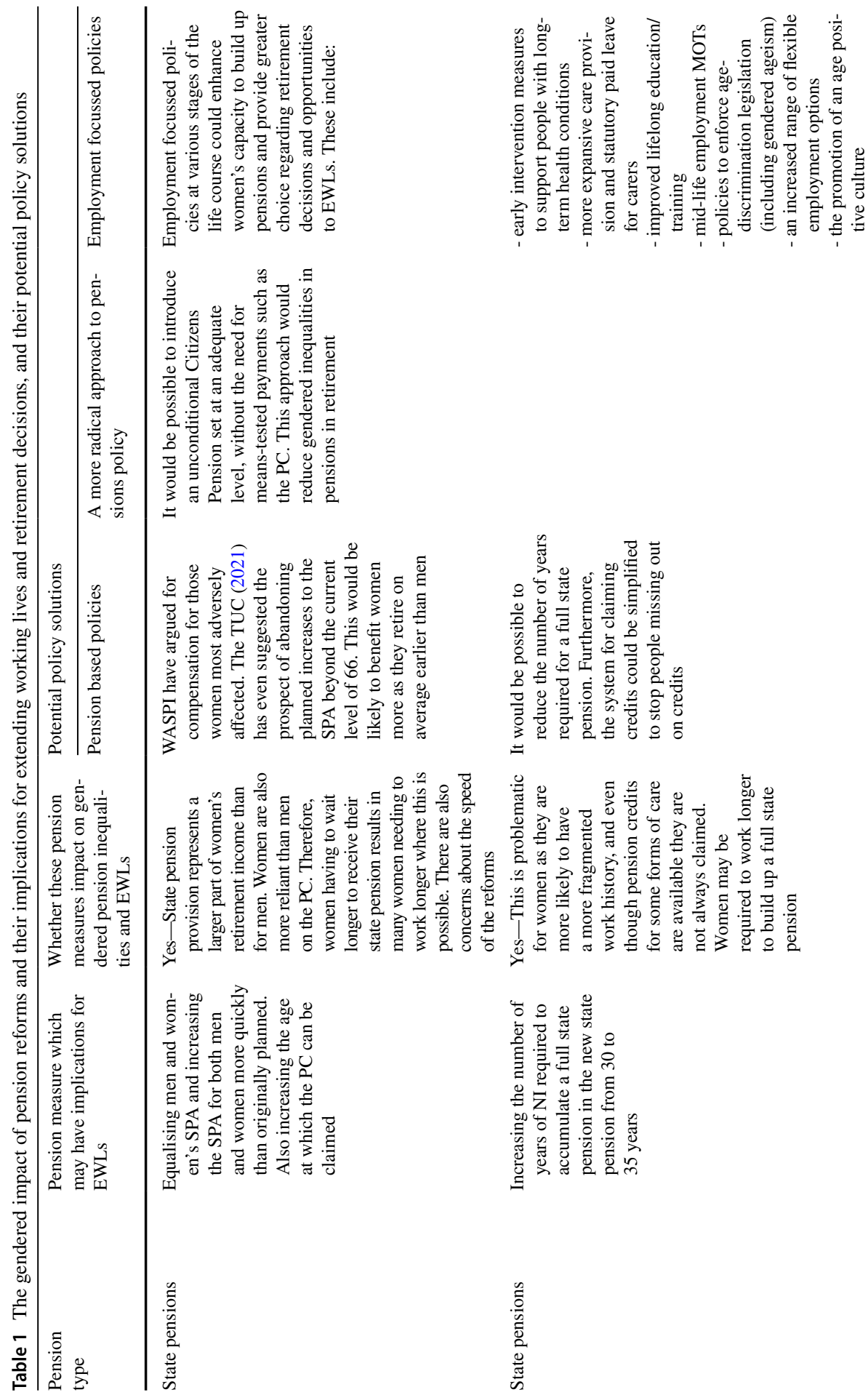




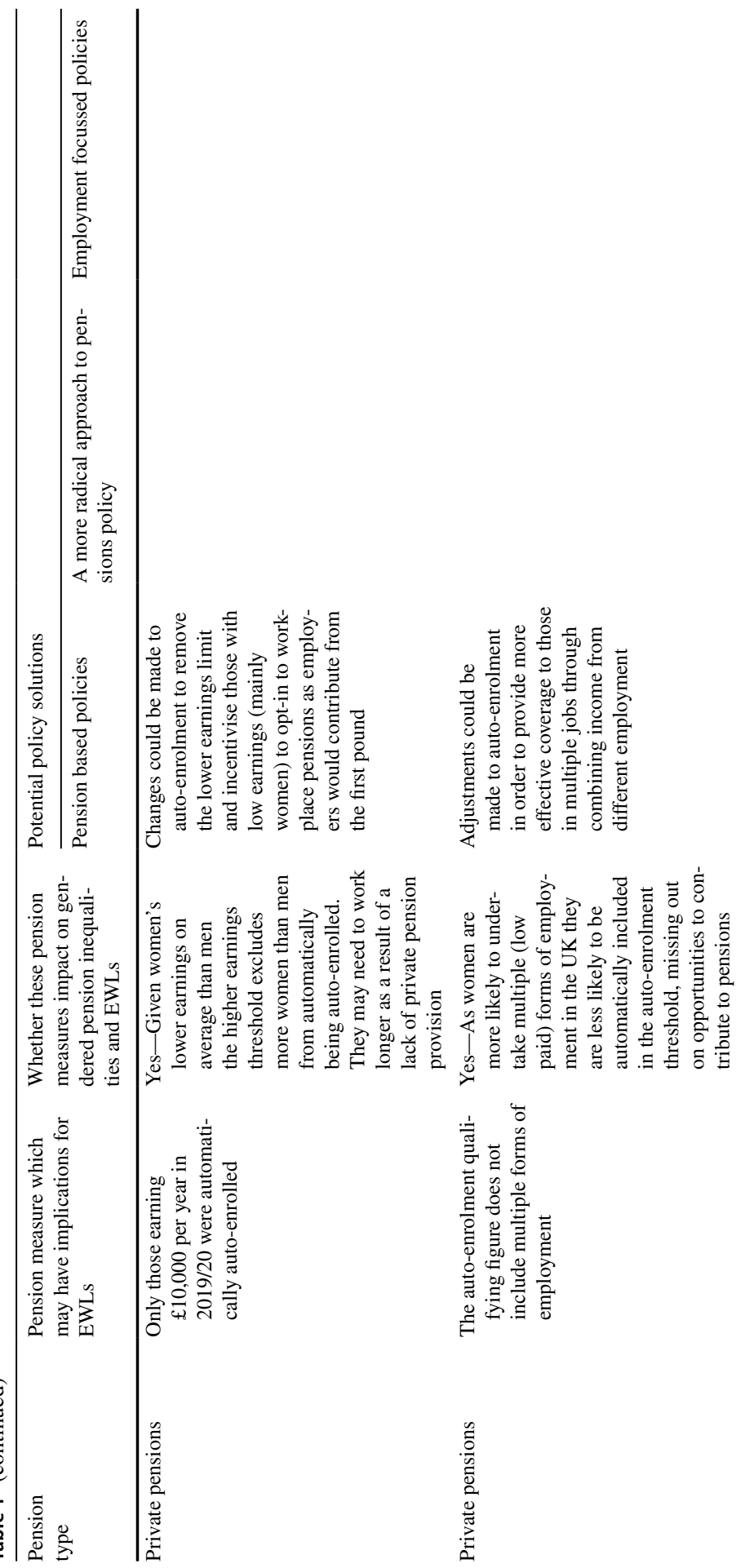




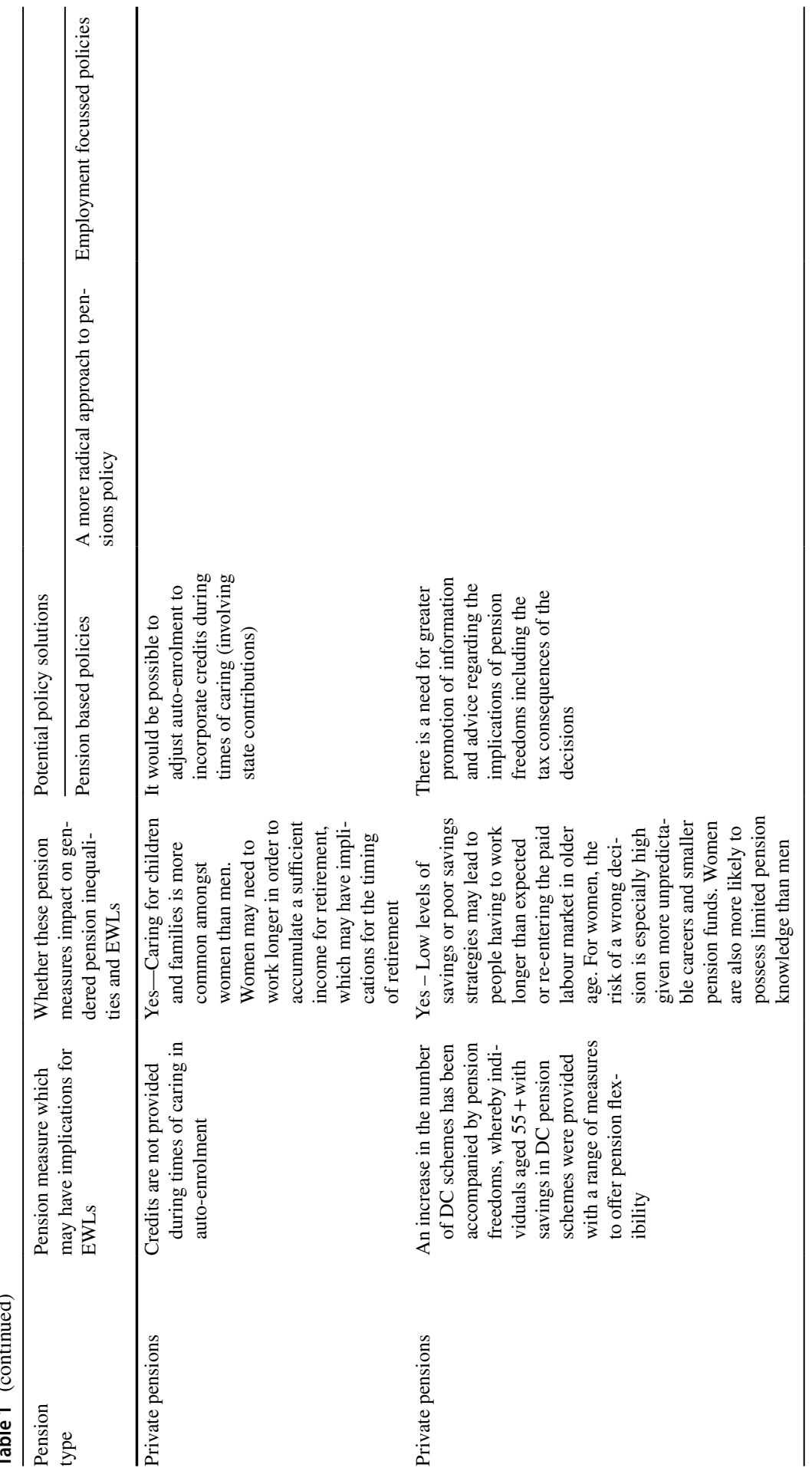


In private pensions adjustments could be made to auto-enrolment to provide more effective coverage to those in multiple jobs (Beach \& Bedell, 2019; PPI, 2016), including those under 22, and removing the lower earnings limit would incentivise those with low earnings (predominantly women) to opt-in to a workplace pension given that employers would contribute from the first pound (Jethwa, 2019). If the earnings trigger and earnings bands were to be removed the PPI (2016) stated that $6 \%$ of men and $22 \%$ of women could be made eligible for autoenrolment. In order to provide some recognition of women's diverse employment histories, auto-enrolment could include credits during times of caring (Ginn \& MacIntyre, 2013). Furthermore, the moves towards DC schemes and the introduction of pension freedoms needs to be accompanied by clear guidance regarding the implications of decision-making to ensure poor saving strategies are not put in place, especially given women on average have lower pension pots.

Table 1 also shows how a more radical approach to assist women's pensions situation and choices around retirement could be taken. It would be possible to substantially redevelop pension systems in a way which serves to de-couple retirement income from labour market participation (Strauss, 2014) thus avoiding the penalty for caring years incurred in private pensions (Ginn \& MacIntyre, 2013; Foster \& Heneghan, 2018). One option is to introduce an unconditional Citizens Pension set at an adequate level, without the need for means-tested payments such as the PC, which are unpopular and underutilised (Ní Léime \& Street, 2017). Foster \& Heneghan (2018) has previously noted that this approach would have the effect of reducing gendered inequalities in pensions in retirement and provide a greater acknowledgement of the importance of a life-course approach to ageing. This is important because carers' valuable unpaid work is seldom addressed properly in pension policy associated with EWLs (Street \& Ní Léime, 2020).

These increases in pension ages in addition to the more limited early retirement opportunities play a crucial role in encouraging extending working lives, but these policies need to not be in isolation from improvements to the quality of work, providing choices and opportunities for women to work longer (Phillipson et al., 2016; Wildman, 2020). A selection of policies is touched upon in Table 1, which would provide women further opportunities to increase their pension contributions throughout the life course, as well as enabling greater choices and opportunities in later life regarding pension decisions and EWLs. For instance, pension policies need to be accompanied by early intervention measures to support people with long-term health conditions, provision of and distribution of care provision, and an overhaul of the system of lifelong education and training (Phillipson et al., 2016). In later life policies to enforce age-discrimination legislation (including gendered ageism), statutory paid leave for carers, support for workers with health conditions, the promotion of an age positive culture and an increased range of flexible employment options could all enhance older women's (and men) opportunities and experiences of EWLs (Airey \& Jandrić, 2020; House of Commons Women and Equalities Committee (WEC), 2018). However, it is important to emphasise that opportunities to work longer will not be available to all and adequate benefit provision is required for those not in a position to EWL (Lain, 2016). 


\section{Conclusion}

Taking a feminist political-economy perspective which incorporates a lifecourse perspective enables an exploration of the structural constraints that shape EWLs and pensions. It has shown that pensions policies can have an important role in EWLs in addition to providing an adequate income in retirement. It is apparent that older women are relatively disadvantaged, in terms of both gender wage gaps and gender pension gaps (Foster, 2017). However, women's existing disadvantages in employment and pensions have been predominantly ignored in the development of EWLs policy, which have perpetuated or expanded many women's financial disadvantage in older age (Ní Léime \& Street, 2017). Recent reforms associated with EWLs have been characterised by a marketization of pensions, greater individual responsibility and diminishing redistribution through pension systems (Ebbinghaus, 2015). These include limited recognition of women's typical paid employment and unpaid caring patterns over the life-course (Jandrić et al., 2019). It has shown how a one size fits all model to EWLs does not adequately represent the heterogeneity of women's work and pensions experiences, with some women unable to extend their working lives due to ill-health and care responsibilities, and others 'choosing' to EWLs in response to increasing the SPA, to avoid later-life poverty (Wildman, 2020). Therefore, there needs to be a greater focus on gendered pension inequalities in developing EWLs policy, to ensure they do not adversely impact on women's position. Only then would it be possible to talk about 'policy successes'.

Acknowledgements The author thanks the anonymous referees for helpful and constructive comments on an earlier version of this article. All remaining errors are my own.

Funding This work was supported by Forte - The Swedish Research Council for Health, Working Life and Welfare - Call Challenges for Working Life (Project Title: EIWO - Exclusion and inequality in the latter part of working life: Evidence for political innovation against an inclusive extended working life and sustainable working conditions in Sweden and Europe) (Grant number: 162828)

Conflicts of interest/Competing interests The author has no conflicts of interest to declare that are relevant to the content of this article.

Open Access This article is licensed under a Creative Commons Attribution 4.0 International License, which permits use, sharing, adaptation, distribution and reproduction in any medium or format, as long as you give appropriate credit to the original author(s) and the source, provide a link to the Creative Commons licence, and indicate if changes were made. The images or other third party material in this article are included in the article's Creative Commons licence, unless indicated otherwise in a credit line to the material. If material is not included in the article's Creative Commons licence and your intended use is not permitted by statutory regulation or exceeds the permitted use, you will need to obtain permission directly from the copyright holder. To view a copy of this licence, visit http://creativecommons.org/licen ses/by/4.0/.

\section{References}

Airey, L., \& Jandrić, J. (2020). United Kingdom. In A. Ni Léime, J. Ogg, M. Rašticová, D. Street, C. Krekula, M. Bédiová, \& I. Madero-Cabib (Eds.), Extending working life policies: International gender and health perspectives (pp. 469-479). London: Springer. 
Altmann, R. (2015). A new vision for older workers: Retain, retrain, recruit. Department for Work and Pensions.

Beach, B., \& Bedell, G. (2019). The EXTEND project: Exploring pension reforms, work and inequality. ILC.

Berry, C. (2021). Pensions imperilled: The political economy of private pensions provision in the UK. Oxford University Press.

Botti, F., Corsi, M., \& D'Ippoliti, C. (2011). Active ageing and gender equality: A labour market perspective document de travail working paper No.11-13. Brussels.

Brown, P., \& Vickerstaff, S. (2011). Health subjectivities and labour market participation: Pessimism and older workers' attitudes and narratives around retirement in the UK. Research on Ageing, 33, $529-550$.

Carrino, L., Glaser, K., \& Avendano Pabon, M. (2018). Later pension, poorer health? Evidence from the new state pension age in the UK. Harvard Center for Population and Development Studies Working Paper Series, 117(4)

Chandler, D., \& Tetlow, G. (2014). Retirement in the 21st century. IFS Report, No. R98. London: JRF/ IFS.

Citizen's Advice Bureau (2017). People in multiple jobs missing out on a workplace pension, reveals Citizens Advice. Retrieved from https:/www.citizensadvice.org.uk/about-us/how-citizens-advice-works/ media/press-releases/people-missing-out-on-workplace-pensions/. Accessed 22 Feb 2017.

Clark, G., \& Strauss, K. (2008). Individual pension-related risk propensities: The effect of sociodemographic characteristics and spousal entitlement on risk attitudes. Ageing and Society, 28(6), $847-874$.

Clark, G., Strauss, K., \& Knox-Hayes, J. (Eds.). (2012). Saving for retirement: Intention, context and behaviour. Oxford University Press.

Crawford, R., Keynes, S., \& Tetlow, G. (2013). A single-tier pension. What does it really mean? JRF/IFS.

Cribb, J., Emmerson, C., \& Tetlow, G. (2014). Labour supply effects of increasing the female state pension age in the UK from age 60 to 62, Institute for Fiscal Studies (IFS), Working paper no. 14/1, Retrieved from http://www.ifs.org.uk/uploads/publications/wps/wp201419.pdf. Accessed 10 Aug 2021.

Cridland, J. (2017). Smoothing the transition: Independent review of the state pension age. Independent report. HMSO. Retrieved from https://www.gov.uk/government/publications/state-pension-ageindependent-review-final-report. Accessed 23 Sep 2018.

Della Giusta, M., \& Longhi, S. (2020). Stung by pension reforms: The impact of a change in state pension age on mental health and life satisfaction of affected women, IZA Discussion Papers, No. 13587. Bonn: Institute of Labor Economics (IZA).

Department for Work and Pensions (DWP). (2014). Fuller working lives: A framework for action. DWP.

Department for Work and Pensions (DWP). (2017). Fuller working Lives: A partnership approach. DWP.

Department of Work and Pensions (DWP). (2017). Automatic enrolment review 2017: Maintaining the Momentum. DWP.

Department of Work and Pensions (DWP). (2020). Automatic enrolment evaluation report 2019. DWP.

Depp, C., \& Jeste, D. (2006). Definitions and predictors of successful ageing: A comprehensive review of larger quantitative studies. American Journal of Geriatric Psychiatry, 14, 6-20.

Di Gessa, G., Corna, L., Platts, L., Worts, D., McDonough, P., Sacker, A., Price, D., \& Glaser, K. (2017). Is being in paid work beyond state pension age beneficial for health? Evidence from England using a life-course approach. Journal of Epidemiology Community Health, 71(5), 431-438.

Dixon, A. (2020). The age of ageing better?: A manifesto for our future. Bloomsbury Publishing.

Ebbinghaus, B. (2015). The privatization and marketization of pensions in Europe: A double transformation facing the crisis. European Policy Analysis, 1(1), 56-73.

Ebbinghaus, B. (2021). Inequalities and poverty risks in old age across Europe: The double-edged income effect of pension systems. Social Policy \& Administration, 55(3), 440-455.

Ebbinghaus, B., \& Hofäcker, D. (2013). Revising early retirement in advanced welfare economies: A paradigm shift to overcome push and pull factors. Comparative Population Studies, 38, 807-840.

Financial Conduct Authority (FCA). (2017). Retirement outcomes review. Interim Report. London: FCA.

Finch, N. (2014). Why are women more likely than men to extend paid work? The impact of work- family life history. European Journal of Ageing, 11(1), 31-39.

Foster, L. (2010). Towards a new political economy of pensions? The implications for women. Critical Social Policy, 30(1), 27-47. 
Foster, L. (2017). Young people and attitudes towards pension planning. Social Policy \& Society, 16(1), 65-80.

Foster, L. (2018). Active ageing, pensions and retirement in the UK. Journal of Population Ageing, 11(2), $117-13$.

Foster, L., \& Heneghan, M. (2018). Pensions planning in the UK: A gendered challenge. Critical Social Policy, 38(2), 345-366.

Foster, L. \& Walker, A. (2021). Active ageing across the life course: towards a comprehensive approach to prevention. BioMed Research International, 1-11.

Ginn, J. (2003). Gender, pensions and the lifecourse: How pensions need to adapt to changing family forms. Policy Press.

Ginn, J., \& MacIntyre, K. (2013). UK pension reforms: Is gender still an issue? Social Policy and Society, 13(1), 91-103.

Grady, J. (2015). Gendering pensions: Making women visible. Gender, Work and Organization, 22(5), $445-458$.

Hallerod, B., Orestig, J., \& Stattin, M. (2013). Leaving the labour market: The impact of exit routes from employment to retirement on health and wellbeing in old age. European Journal of Ageing, 10(1), 25-35.

Hannah, L. (1986). Inventing retirement: The development of occupational pensions in Britain. Cambridge University Press.

Higgs, P., \& Gilleard, C. (2010). Generational conflict, consumption and the ageing welfare state in the United Kingdom. Ageing and Society, 30, 1439-1451.

Hofäcker, D., Hess, M., \& König, S. (Eds.). (2016). Delaying Retirement: Progress and Challenges of Active Ageing in Europe, the United States and Europe. Palgrave Macmillan.

Holman, D., Foster, L., \& Hess, M. (2020). Inequalities in women's awareness of changes to the State Pension Age in England and the role of cognitive ability. Ageing \& Society, 40(1), 144-161.

James, H., Price, D., \& Buffel, T. (2020). How do people think about later life when making workplace pension saving decisions? Journal of Aging Studies, 54, 100869.

Jandrić, J., Airey, L., Loretto, W., \& Vickerstaff, S. (2019). Research paper DAISIE country report: United Kingdom, Retrieved July 23, 2021, from https://doi.org/10.12682/lives.2296-1658.2019. 77.32019.

Jethwa, C. (2019). Understanding the gender pensions gap. Pension Policy.

Kohli, M. (2007). The institutionalization of the lifecourse: Looking back to looking ahead. Research in Human Development, 4(3-4), 253-271.

Krekula, C., \& Vickerstaff, S. (2017). Theoretical and conceptual issues in the extended working lives agenda. In Á. NíLéime, D. Street, S. Vickerstaff, C. Krekula, \& W. Loretto (Eds.), Gender, ageing and extended working life: Cross-national perspectives (pp. 27-52). London: Policy Press.

Krekula, C., \& Vickerstaff, S. (2020). The older worker and the ideal worker: A critical examination of concepts and categorisations in the rhetoric of extending working lives. In A. Ní Léime, J. Ogg, M. Rašticová, D. Street, C. Krekula, M. Bédiová, \& I. Madero-Cabib (Eds.), Extending working life policies: International gender and health perspectives (pp 29-46). London: Springer.

Kuitto, K., \& Helmdag, J. (2021). Extending working lives: How policies shape retirement and labour market participation of older workers. Social Policy and Administration, 55(3), 423-439.

Kuitto, K., Kuivalainen, S., \& Möhring, K. (2021). Inequalities in pensions and retirement from a lifecourse perspective: An introduction. Social Policy and Administration, 55(3), 403-408.

Lain, D. (2016). Reconstructing retirement: Work and welfare in the UK and USA. Policy Press.

Lain, D., \& Loretto, W. (2016). Managing employees beyond age 65: From the margins to the mainstream? Employee Relations, 38(5), 646-664.

Lain, D., Van der Horst, M., \& Vickerstaff, S. (2019). Extending working lives: Feasible and desirable for all? In S. J. Czaja, J. B. James, J. Grosch, \& J. Sharit (Eds.), Current and emerging trends in aging and work (pp. 101-119). Springer.

Laczko, F., \& Phillipson, C. (1991). Changing work and retirement: Social policy and the older worker. Open University.

Lusardi, A., \& Mitchell, O. (2014). The economic importance of financial literacy: Theory and evidence. Journal of Economic Literature, 51(1), 5-44.

Mabbett, D. (2012). The ghost in the machine: Pension risks and regulatory responses in the United States and the United Kingdom. Politics \& Society, 40(1), 107-129.

MacLeod, P., Fitzpatrick, A., Hamlyn, B., Jones, A., Kinver, A., \& Page, L. (2012). Attitudes to pensions: The 2012 Survey. Research Report No. 813. London: DWP. 
Macnicol, J. (2015). Neoliberalising old age. Cambridge University Press.

Mayhew, L. (2021). On the postponement of increases in state pension age through health improvement and active ageing. Applied Spatial Analysis, 14, 315-336.

McClymont, G., \& Tarrant, A. (2016). Towards a new pension settlement: An international perspective. London: Rowman and Littlefield International.

Möhring, K. (2021). The consequences of non-standard working and marital biographies for old age income in Europe: Contrasting the individual and the household perspective. Social Policy \& Administration, 55(3), 456-484.

Ní Léime, Á., \& Street, D. (2017). Gender and age implications of extended working life policies in the US and Ireland. Critical Social Policy, 37(3), 464-483.

Ní Léime, Á., \& Loretto, W. (2017). Gender perspectives on extended working life policies. In Á. NíLéime, D. Street, S. Vickerstaff, C. Krekula, \& W. Loretto (Eds.), Gender, Ageing and Extended Working Life: Cross-national Perspectives (pp. 53-75). London: Policy Press.

Ní Léime, A., Ogg, J., Rašticová, M., Street, D., Krekula, C., Bédiová, M., \& Madero-Cabib, I. (Eds.). (2020). Extending working life policies: International gender and health perspectives. London: Springer.

von Nordheim, F. (2016). The 2015 pension adequacy report's examination of extended working lives as a route to future pension adequacy. Intereconomics, 51, 125-134.

Now: Pensions (2016). NOW: Pensions calls for changes to auto enrolment legislation to end 'covert sexual discrimination. Retrieved from https:/www.nowpensions.com/press-release/now-pensi ons-calls-changes-auto-enrolment-legislation-end-covert-sexual-discrimination/. Accessed 21 July 2021.

Now: Pensions (2018). How can we bridge the gender pensions gap? Retrieved from https://www.nowpe nsions.com/blog/how-can-we-bridge-the-gender-pensions-gap/. Accessed 21 July 2021.

ONS (2018). Individual private pension wealth by age and sex: Great Britain, July 2014 to June 2016. Dataset. Office for National Statistics. Retrieved from https:/www.ons.gov.uk/peoplepopulatio nandcommunity/personalandhouseholdfinances/pensionssavingsandinvestments/adhocs/00814 6individualprivatepensionwealthbyageandsexgreatbritainjuly2014tojune2016. Accessed 1 Oct 2018.

ONS (2020). National life tables - life expectancy in the UK: 2017 to 2019, Retrieved from https://www. ons.gov.uk/peoplepopulationandcommunity/birthsdeathsandmarriages/lifeexpectancies/bulletins/ nationallifetablesunitedkingdom/2017to2019. Accessed 1 Mar 2021.

OECD. (2006). Live Longer. Paris, OECD Publishing.

OECD (2018). Ageing and employment policies: United States 2018 working better with age and fighting unequal ageing. OECD publishing. Retrieved from https://read.oecd-ilibrary.org/employment/ ageing-and-employment-policies-united-states-2018_9789264190115-en\#page23. Accessed 3 June 2019.

Pemberton, H. (2017). WASPI's is (mostly) a campaign for inequality. The Political Quarterly, 86(3), 510-516.

Phillipson, C. (1982). Capitalism and the construction of old age. London: Macmillan.

Phillipson, C., \& Smith, A. (2006). Extending working life: A review of the research literature. Department for Work and Pensions.

Phillipson, C., Vickerstaff, S., \& Lain, D. (2016). Achieving fuller working lives: Labour market and policy issues in the United Kingdom. Australian Journal of Social Issues, 51(2), 187-204.

Phillipson, C., Shepherd, S., Robinson, M., \& Vickerstaff, S. (2019). Uncertain futures: Organisational influences on the transition from work to retirement. Social Policy and Society, 18(3), 335-350.

Phillipson, C. (2019). 'Fuller' or 'extended' working lives: Critical perspectives on changing transitions from work to retirement. Ageing and Society, 39(3), 629-650.

Pensions Policy Institute (PPI). (2016). The under-pensioned 2016. TUC/JRF/AGEUK.

Pension Policy Institute (PPI). (2018). The impact of the introduction of automatic enrolment on future generations PPI Briefing Note Number 105. London: PPI.

Porcellato, L., Carmichael, F., Hulme, C., Ingham, B., \& Prashar, A. (2010). Giving older workers a voice: Constraints on the employment of older people in the North West of England. Work, Employment and Society, 24(1), 85-103.

Price, D. (2007). Closing the gender gap in retirement income: What difference will recent UK pension reforms make? Journal of Social Policy, 36(4), 561-583.

Price, D. (2015). Financing later life: Why financial capability agendas may be problematic. Working with Older People, 19(1), 41-48. 
Prabhakar, R. (2017). Why do people opt-out or not opt-out of automatic enrolment? A focus group study of automatic enrolment into a workplace pension in the United Kingdom. Journal of European Social Policy, 27(5), 447-457.

Powell, J., \& Taylor, P. (2016). Rethinking risk and ageing: Extending working lives. Social Policy and Society, 15(4), 637-645.

Principi, A., Santin, S., Socci, M., Smeaton, D., Cahill, K., Vegeris, S., \& Barnes, H. (2018). Retirement plans and active ageing: Perspectives in three countries. Ageing and Society, 38(1), 56-82.

Scottish Widows (2019). Women and pensions report 2019, Retrieved from https://adviser.scottishwi dows.co.uk/assets/literature/docs/2019-women-retirement-report.pdf. Accessed 3 June 2020.

Strauss, K. (2014). Accessing pension resources: The right to equality inside and out of the labour market. International Journal of Law in Context, 10(4), 522-537.

Street, D., \& Ní Léime, Á., et al. (2020). Problems and Prospects for Current Policies to Extend Working Lives. In J. Ogg, M. Rašticová, D. Street, C. Krekula, \& M. Bédiová (Eds.), Extended Working Life Policies: International Gender and Health Perspectives (pp. 85-113). London: Springer.

Swain, J., Carpentieri, J., Parsons, S., \& Goodman, A. (2020). Using a lifecourse perspective to understand early labor market exits for people in their late 50s living in the UK. International Journal of Ageing and Later Life, 14(2), 163-192.

Taylor, P., Earl, C., Brooke, E., \& McLoughlin, C. (2021). Retiring Women: Work and Post-work Transitions. Edward Elgar.

Taylor, P., \& Earl, C. (2016). The social construction of retirement and evolving policy discourse of working longer. Journal of Social Policy, 45(2), 251-268.

Thaler, R., \& Benartzi, S. (2004). Save more tomorrow: Using behavioral economics to increase employee saving. Journal of Political Economy, 112(1, part 2), S164-S196.

Thaler, R., \& Sunstein, C. (2008). Nudge: Improving decisions about health, wealth and happiness. Yale University Press.

Thurley, D., \& Keen, R. (2018). State pension age increases for women born in the 1950s, Briefing Paper Number CBP-7405.

Thurley, D., \& McInnes, R. (2019). State pension age increases for women born in the 1950s. Briefing Paper CBP-7405. House of Commons Library.

TUC (2021). Extending working lives How to support older workers, Retrieved from https://www.tuc.org. uk/research-analysis/reports/extending-working-lives-how-support-older-workers. Accessed 5 July 2021.

Vickerstaff, S. (2006). Entering the retirement zone: How much choice do individuals have? Social Policy and Society, 5(4), 507-517.

Vickerstaff, S., \& Cox, J. (2005). Retirement and risk: The individualisation of retirement experiences? Sociological Review, 53(1), 77-95.

Vickerstaff, S., \& Loretto, W. (2017). The United Kingdom-A new moral imperative: Live longer, work longer. In A. NíLéime, D. Street, S. Vickerstaff, C. Krekula, \& W. Loretto (Eds.), Gender, ageing and extended working life: Cross-national perspectives (pp. 175-192). Bristol: Policy Press.

Wahrendorf, M., Akinwale, B., Landy, R., Matgthews, K., \& Blane, D. (2017). Who in Europe Works beyond the State Pension Age and under which Conditions? Results from SHARE. Population Ageing, 10(3), 269-285.

Wainwright, D., Crawford, J., Loretto, W., Phillipson, C., Robinson, M., Shepherd, S., Vickerstaff, S., \& Weyman, A. (2019). Extending Working Life and the Management of Change. Is the Workplace Ready for the Ageing Worker? Ageing and Society, 39(11), 2397-2419.

Webb, S. (2014). Steve Webb: New state pension will treat women as 'adults in their own right', The Telegraph, Retrieved from http://www.telegraph.co.uk/finance/personalfinance/pensions/11036468/. Accessed 25 July 2020.

Weyman, A., Wainwright, D., O’Hara, R., Jones, P., \& Buckingham, A. (2012). Extending working life: Behaviour change intervention. London: Department for Work and Pensions.

Wicks, R., \& Horack, S. (2009). Incentives to save for retirement: Understanding, perceptions and behaviour - a literature review. Leeds: Stationery Office, Research Report No. 562.

Wildman, J. (2020). Life-Course influences on extended working: Experiences of women in a UK babyboom birth cohort. Work, Employment and Society, 34(2), 211-227.

Women's Budget Group (2020). Pensions and gender: Briefing from the UK Women's Budget Group on pension gender inequality October 2019, Retrieved from https://wbg.org.uk/wp-content/uploads/ 2019/10/PENSIONS-2019-1.pdf. Accessed 6 July 2021. 
WEC (2018). Older people and employment. Fourth report of the session 2017-2019. House of Commons Women and Equalities Committee. Retrieved from https://publications.parliament.uk/pa/ cm201719/cmselect/cmwomeq/359/359.pdf. Accessed 27 July 2018.

Work and Pensions Committee (2015). House of Commons - Communication of state pension age changes. Retrieved from https://publications.parliament.uk/pa/cm201516/cmselect/cmworpen/899/ 89906.htm. Accessed 27 July 2018.

Publisher's Note Springer Nature remains neutral with regard to jurisdictional claims in published maps and institutional affiliations. 